\title{
HYALOMMA TICKS: BOVINE RESISTANCE UNDER FIELD CONDITIONS AS RELATED TO HOST AGE AND BREED
}

\author{
SAHIBI H.*, RHALEM A.*, TIKKI N.**, BEN KOUKA F.** \& BARRIGA O.***
}

Summary :

Field collection of ticks from two breeds of cattle [Native breed (local) and purebred (Friesian)], showed that the number of ticks was higher on purebred than on native cattle.

The susceptibility seemed to increase with the age of the animals. Furthermore, breed appeared to exert more influence than age. There was no correlation between the number of ticks associated with each animal, the antibody production and antigens recognized. The immune response under field condition looked more like immune suppression than immune protection.

KEY WORDS : ticks, Hyalomma spp., cattle, age, breed, resistance, humoral response, antigens.

\section{INTRODUCTION}

Ticks are well known hematophagous ectoparasites and are vectors of pathogens which cause diseases in man and livestock (Balashov, 1972).

It has long been recognized that various breeds of cattle differ in their response to tick infestations (Latif, 1984a; Rechav \& Kostrzewski, 1991). Some breeds have low infestation rates and are considered resistant, while others cannot control the number of ticks and are referred to as susceptible breeds.

Johnston \& Bancroft (1918), were the first to report resistance to Boophilus microplus Canestrini (1887) infestation in European dairy cattle. Since then, naturally acquired resistance of cattle to tick infestation has been well documented (Morrison, 1989; Tatchell, 1987; Fivaz \& Norval, 1990; George et al., 1985).

The occurrence of comparative resistance of local cattle and breeds of importation to local ticks of the

* Département de Parasitologie et Maladies Parasitaires, Institut Agronomique et Vétérinaire Hassan II, BP 6202, Rabat, Maroc.

** Département de Biochimie, Faculté des sciences de Rabat.

*** Department of Veterinary Preventive Medicine, 1900 Coffey Road, Columbus, Ohio 43210-1092, USA.

Correspondence: Hamid Sahibi. Tel: 771745 - Fax: 778135 .
Résumé : Degré d'INFestation de bOVINS PAR LES TIQUes SELON LEUR RACE ET LEUR ÂGE

La collecte des tiques de deux races génétiquement différentes, la race locale et la race Frisonne pie noire, a montré que le degré

d'infestation de la race Frisonne est plus important que celui de la race locale. La sensibilité aux tiques semble augmenter avec l'âge des animaux.

Par ailleurs, aucune corrélation entre le degré d'infestation, la production d'anticorps et les antigènes reconnus n'a été démontrée. Il s'est avéré que dans les conditions naturelles, la réponse immunitaire vis-à-vis des tiques n'est pas protectrice.

MOTS CLÉS : tiques, Hyalomma spp., bovin, âge, race, résistance, réponse humorale, antigènes. genera, Rhipicephalus, Boophilus and Hyalomma has received recent attention. Some authors (Fivaz et al., 1991) found that European dairy breeds can develop resistance to the three-host African ticks Amblyomma bebraeum Koch (1844). Others found that under field conditions a higher number of ticks were recovered from breeds Hereford and Simmentaler than from Brahman or Nguni (Rechav et al., 1990; Rechav \& Kostrzewski, 1991). This paper shows the effects of age and breed on tick infestation and tick feeding efficiency. The antibody production in naturally infested cattle is also considered.

\section{MATERIALS AND METHODS}

\section{REGION}

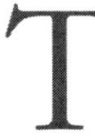

he study was carried out at 4 farms selected in a sub-humid region (Kenitra), with a mean annual rainfall of $596 \mathrm{~mm}$. In August, the mean of maximum temperature is $33^{\circ} \mathrm{C}$, and in January the mean of minimum temperature is $5{ }^{\circ} \mathrm{C}$. Kenitra is known as a diversified agricultural region. The natural vegetation is dominated by forests of Quercus suber accompagned with Chamaerops bumilis. 


\section{ANIMALS}

The first survey was undertaken during the high risk periods of infestation (May, June, July, August), to show the effects of age and breed on tick infestations. This was done on thirty-two animals, eight native particular (local) breed and eight purebred (Friesian, first importation was done in 1974) below one year of age, and eight native (local) breed and eight purebred above four years.

The second survey was conducted during a whole year in order to follow antibody production. Each month, thirty-two cattle as described above were examined. The ticks were counted and not retrieved.

All cattle were identified with ear-tags and treated with an acaricide twice, two weeks apart before starting the study.

\section{TICK AND BLOOD COLLECTION}

Each animal was examined carefully and any ticks present were removed and stored in tubes. Males and females were kept in tubes containing $10 \%$ alcohol in water. Collection of ticks were done twice a month during the period of high risk infestation (May to August), and once a month during the other months of the year. On each occasion, the species of ticks infesting each animal were determined using Morel's key (1976). Blood was collected once a month throughout the year.

\section{PREPARATION OF ANTIGENS}

Antigens were prepared from the most prevalent ticks collected. Five day fed females of Hyalomma marginatum Koch, 1844, H. detritum Schulze, 1919, H. anatolicum Koch, 1844 and H. lusitanicum Koch, 1844, reared under laboratory conditions. The ticks were washed in several solutions of $70 \%$ alcohol and in Phosphate Buffer Saline (PBS). The female ticks were fixed in wax and their salivary glands removed and placed in PBS (10 salivary glands $/ 50 \mu \mathrm{l})$. The aliquot was sonicated (10 times) at full power, 30 seconds each time in ice. The homogenates were then centrifuged at $10,000 \mathrm{~g}$ at $4{ }^{\circ} \mathrm{C}$ for $15 \mathrm{~min}$ and the supernatants stored at $-20^{\circ} \mathrm{C}$. The protein content was determined by the method of Lowry et al. (1951).

\section{ELISA}

The animals of the second survey, were bled via the jugular vein and individual sera were collected, aliquoted and stored at $-20{ }^{\circ} \mathrm{C}$ until used. An ELISA test was used to asses the antibody production. The procedure followed was described by Engvall \& Perlman (1971). Ninety-six-well flat-bottom microplates [Probind (Becton Dickson)] were coated with $5 \mu \mathrm{g} /$ well of protein antigens derived from a mixture of the five days fed salivary glands, diluted in carbonate bicarbonate coating buffer, $\mathrm{pH}=9.6$ and incubated two hours at $37{ }^{\circ} \mathrm{C}$ and over/night at $4^{\circ} \mathrm{C}$. After three washings with PBS containing Tween 20 at $0.05 \%$ (PBS-T $0.05 \%$ ), the microplates were incubated one hour at $37{ }^{\circ} \mathrm{C}$ with PBS containing Tween 20 at $2 \%$ (PBS-T $2 \%$ ), in order to inhibit non specific binding. Three rinsings with PBS-T $0.05 \%$ were done, and $100 \mu \mathrm{l}$ of cattle sera diluted to $1 / 100$ in PBS-T $0.05 \%$ were added (all samples were tested in triplicate) and plates were incubated for one hour at $37^{\circ} \mathrm{C}$. After wash, $100 \mu \mathrm{l}$ of peroxidase labelled rabbit anti-bovine IgG (Cappel Lab. Westchester Pensylvania), diluted at 1/1,000 were added to each well. The plates were incubated for an additional hour at $37^{\circ} \mathrm{C}$, and after another three washings with PBS-T $0.05 \%, 100 \mu$ of substrate solution (Orthophenylene diamine $(10 \mathrm{mg})+1 \mathrm{ml}$ methanol $+100 \mu \mathrm{H} \mathrm{H}_{2} \mathrm{O}_{2}$ and $99 \mathrm{ml}$ water) were added in the wells. The assays were read at an optical wave length of $492 \mathrm{~nm}$ using an automated ELISA plate reader (Titertek Multiscan plus). The optimal antigen, serum and conjugate dilutions were previously determined by checkboard titrations.

\section{WESTERN BLOT}

Electrophoretic transfer and immunodetection of tick antigens was performed essentially as described by Tsang et al. (1983), using Tris-buffer saline $\mathrm{pH}=7.5$ (TBS), $2 \%$ Tween in TBS as a blocking buffer and BioRad horseradish peroxidase (HRPO) color developer containing 4-chloro 1-naphtol.

Extracts from salivary glands were run on 5 to $20 \%$ gradient gel. Separated protein bands were transferred to nitrocellulose paper (NCP), for one hour at $100 \mathrm{~V}$ in electrode solution (Tris $25 \mathrm{~mm}$, glycine $112 \mathrm{~mm}$ at SDS $0.1 \%, \mathrm{pH}=8.3$ ). After transfer, nitrocellulose strips were incubated at room temperature for 1 hour in TBS-T $2 \%$. $\mathrm{NCP}$, were incubated individually in bovine sera diluted at $1 / 100$ in TBS-T $0.2 \%$, for two hours at $37^{\circ} \mathrm{C}$. After washings, the strips were incubated with Rabbit antibovine IgG (heavy and light chains specific) conjugated to HRPO $(1 / 2,000)$ (one hour, $37^{\circ} \mathrm{C}$ ). After three further rinsings with TBS-T $0,05 \%$, the strips were colored with 4-chloro-1-naphtol (60 mg of HRPO color developer dissolved in $20 \mathrm{ml}$ of ice-cold methanol) with $1 \mu \mathrm{l}$ of ice cold $30 \% \mathrm{H}_{2} \mathrm{O}_{2}$ in TBS per $\mathrm{ml}$ added immediately before use. The incubation was done at darck chamber. The strips were rinsed in distilled water when purple bands appeared.

\section{STATISTICAL ANALYSIS}

For each group, the arithmetic mean was calculated and the significance of the difference between means was confirmed by Student and Fisher test $(\mathrm{P}<0.05)$ (Snedecor \& Cochran, 1980). 
RESULTS

$\mathrm{O}$ ur survey showed that young calves have light infestations and old cattle carry heavy infestations (14.5 times more ticks than young calves) $(\mathrm{P}<0.05)$. Female ticks collected from old cattle were almost three times heavier than ticks collected from young animals $(\mathrm{P}<0,05)$ (Fig. 1).

The effect of breed on tick infestation was also significant $(\mathrm{P}<0.05)$ (Fig. 2). The fewest ticks were found on the native breed. The purebred had three times more ticks. However, the effect due to breed on tick feeding was not significant.

The interaction of age and breed on the infestation rate is demonstrated in Table I. Three similar groups were determined statistically. There was no significant difference in infestation rates among any breeds $<1$ year of age, the native breed $>4$ years of age constituted a second group, and the purebred $>4$ years old which was the heaviest infested group.

A similar pattern was obvious when comparing age and breed influences on feeding efficiency of female ticks (Table II). All breeds $<1$ year of age made up a group with the lightest weight of female ticks, and the purebred $>4$ years of age was a group with the heaviest female ticks. The native breed $>4$ years constitutes an intermediate group.

The results presented in Table III confirm the other results and show that over the course of an entire year, young calves are more resistant to tick infestation than adults and that the native breed is the most resistant. The ELISA test showed a wide variability in antibody levels among these animals (Fig. 3A, 3B) and (Fig. 4A, $4 B$ ). Average peaks in aging native breed were higher than the peaks in aging purebred cattle but the results were not statistically significant. There was no difference between young native breed and young pure-

\begin{tabular}{lcc}
\hline \multicolumn{3}{c}{ Average number of ticks } \\
\hline $\begin{array}{c}\text { Breed } \\
\text { age }\end{array}$ & Native & Pure \\
\hline $\mathrm{C}<1$ year & $7.5 \pm 6^{*}$ & $19 \pm 13.5^{*}$ \\
& $\mathrm{G} 1$ & $\mathrm{G} 1$ \\
$\mathrm{C}<4$ years & $87 \pm 26 \#$ & $\mathrm{G} 2$ \\
& $\mathrm{G} 2$ & $\mathrm{G} 3$ \\
\hline $\mathrm{G}=$ statistical group (results followed by the same symbol were not \\
significant).
\end{tabular}

Table I. - Interaction age-breed and its effect on tick infestation.

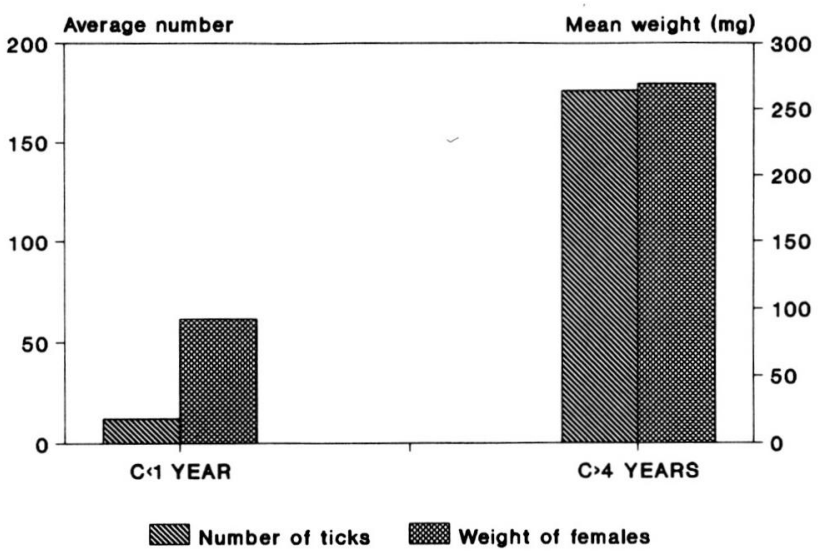

Fig. 1. - Effect of age on tick infestations and on weights of fed female ticks engorged on cattle under field conditions.

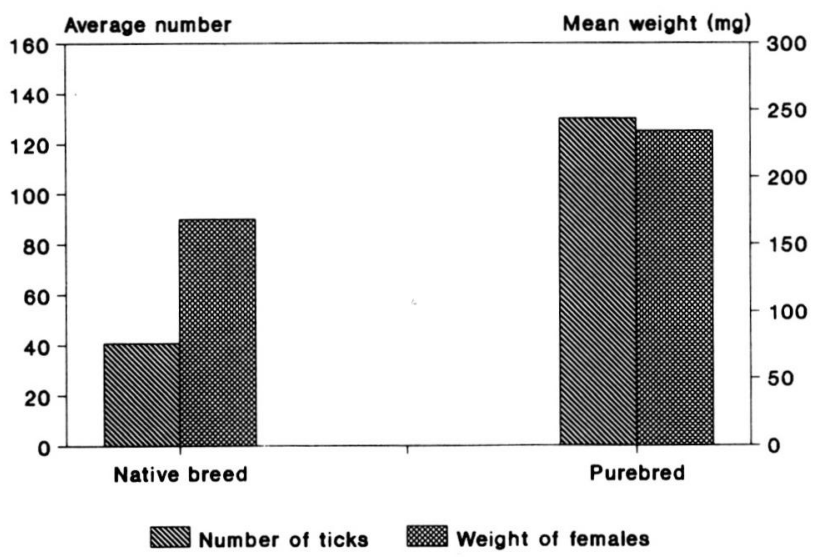

Fig. 2. - Effect of breed on tick infestations and on weights of fed female ticks engorged on cattle under field conditions.

\begin{tabular}{ccc}
\hline \multicolumn{3}{c}{ Weight of collected females (milligrams) } \\
\hline $\begin{array}{c}\text { Breed } \\
\text { age }\end{array}$ & Native & Pure \\
\hline $\mathrm{C}<1$ year & $82 \pm 27^{*}$ & $108 \pm 32^{*}$ \\
& $\mathrm{G} 1$ & $\mathrm{G} 1$ \\
$\mathrm{C}<4$ years & $215 \pm 45 \#$ & $332 \pm 66 \&$ \\
& $\mathrm{G} 2$ & $\mathrm{G} 3$ \\
\hline
\end{tabular}

$\mathrm{G}=$ statistical group (results followed by the same symbol were not significant).

Table II. - Interaction age-breed and its effect on the efficiency of feeding. 


\begin{tabular}{|c|c|c|c|c|}
\hline $\begin{array}{l}\text { Breed-age } \\
\text { animals }\end{array}$ & $\begin{array}{l}\text { Native breed } \\
\text { young }\end{array}$ & $\begin{array}{l}\text { Purebred } \\
\text { young }\end{array}$ & $\begin{array}{l}\text { Native breed } \\
\text { old }\end{array}$ & $\begin{array}{l}\text { Purebred } \\
\text { old }\end{array}$ \\
\hline I & 18 & 48 & 222 & 531 \\
\hline II & 9 & 42 & 148 & 401 \\
\hline III & 17 & 13 & 129 & 283 \\
\hline IV & 7 & 32 & 98 & 453 \\
\hline $\mathrm{V}$ & 12 & 26 & 76 & 302 \\
\hline VI & 19 & 30 & 200 & 500 \\
\hline VII & 10 & 27 & 109 & 339 \\
\hline VIII & 9 & 40 & 88 & 340 \\
\hline Average & $12.6 \pm 4.3$ & $32.2 \pm 12.2$ & $134.6 \pm 50.2$ & $394 \pm 92.8$ \\
\hline
\end{tabular}

Table III. - Average tick number counted (but not retrieved) during a whole year on 8 native and 8 purebred young calves, and 8 native and 8 purebred old cows.
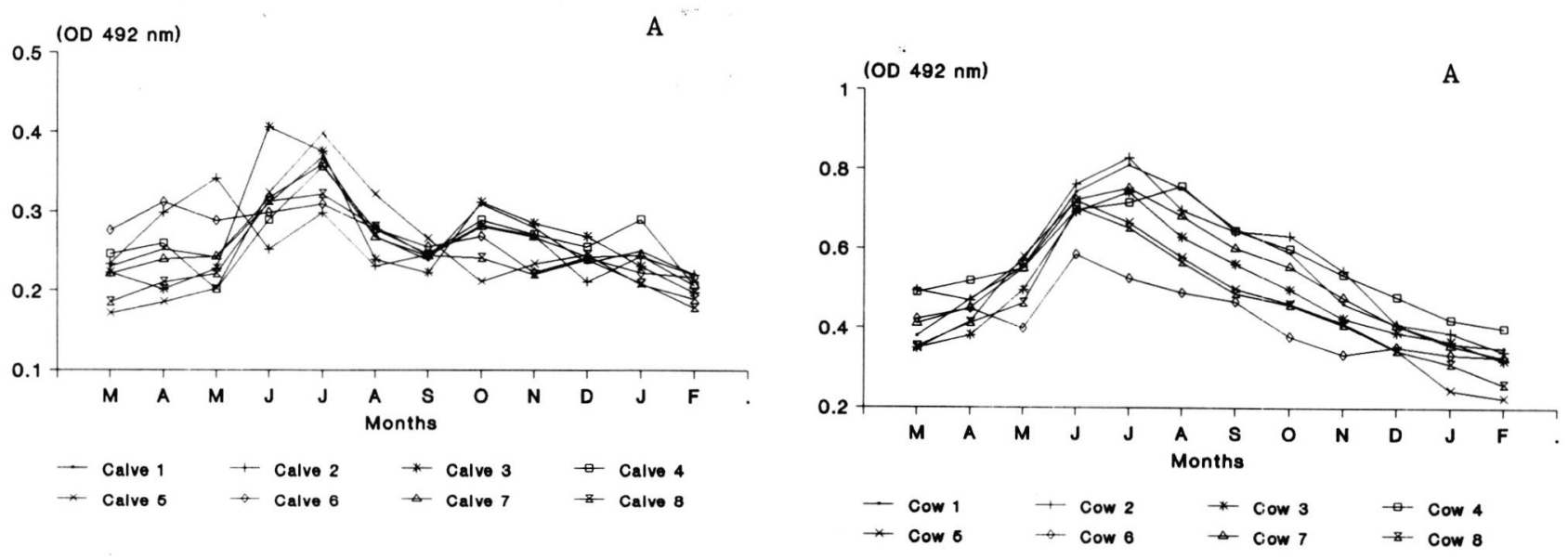

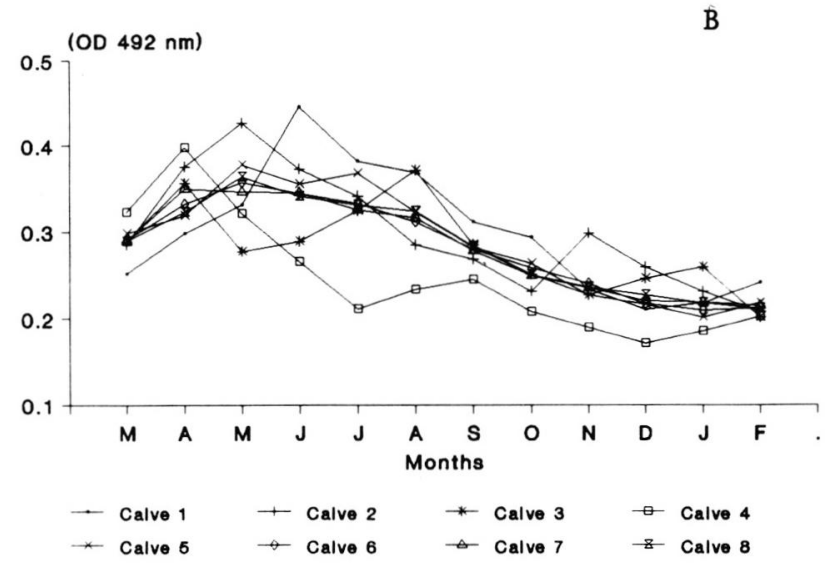

Fig. 3. - Antibody production in naturally infected young native breed calves (A) and young purebred calves (B) against 5-day-fed salivary gland antigens of Hyalomma spp (H. marginatum, $H$. detritum, $H$. anatolicum, $H$. lusitanicum) ticks.

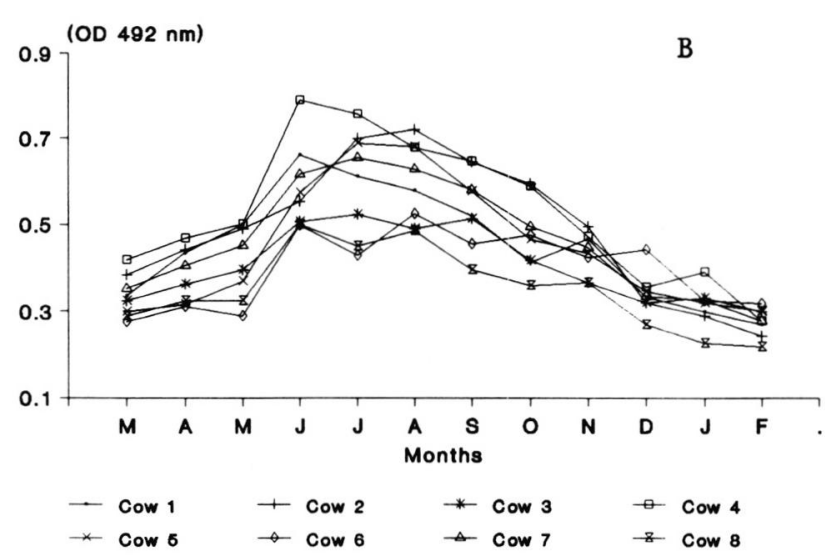

Fig. 4. - Antibody production in naturally infected old native breed calves (A) and old purebred calves (B) against 5-day-fed salivary gland antigens of Hyalomma spp ( $H$. marginatum, $H$. detritum, $H$. anatolicum, $H$. lusitanicum) 
bred. However, the level of antibodies was higher in old calves than in young ones. The highest titers were in June and July corresponding to the peak of tick activity.

Westernblots of salivary gland extracts recognized by sera of high antibody titer from the animals, revealed great variability in the response of each group and showed that young calves recognized fewer antigens than older cattle of both breeds. Young native calves recognized antigens around 18.3 and $28 \mathrm{Kda}$. Four young purebred calves recognized antigens around $18.5 \mathrm{Kda}$ which were also recognized by young native calves (Fig. 5). Older animals of both breeds recognized antigens between 26 and $215 \mathrm{Kda}$ (Fig. 6). However, four native breed and two purebred animals recognized antigens of $15 \mathrm{Kda}$ that were absent in the other animals.

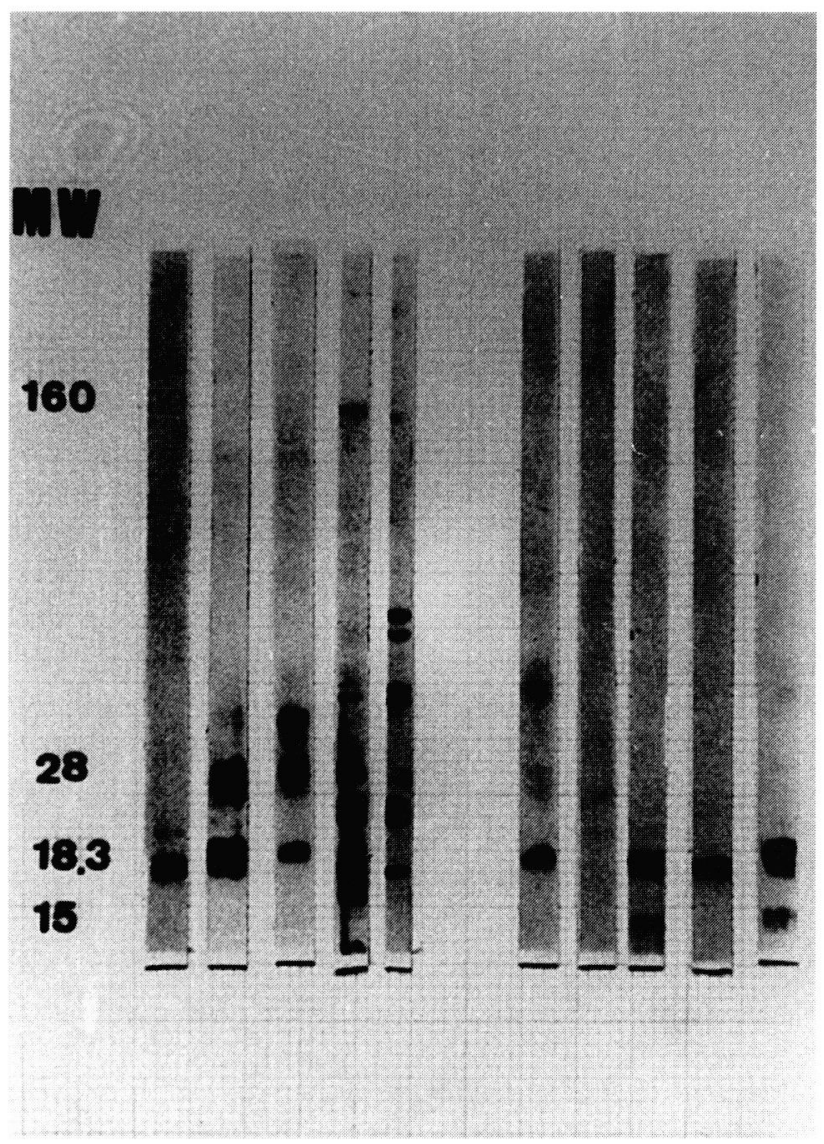

Fig. 5. - Antigens recognized by sera of young native breed calves (right) and young purebred calves (left) in 5-day-fed salivary gland antigens of Hyalomma spp. (H. marginatum, H. detritum, H. anatolicum, H. lusitanicum) ticks.

\section{DISCUSSION}

The concepts of host resistance pioneered by Paul Wilkinson (1955) and followed up by Harry Wahrton et al. (1970) were conclusively demonstrated in a series of papers (Tatchell, 1987) on the acquisition of resistance by Bos taurus and by Bos indicus to Boophilus microplus Canestrini (1887). This resistance depends on breed (Latif, 1984a-b), age (Brown, 1984), and environmental factors, such as nutritional value of the grass consumed by the animals (Rechav \& Hay, 1992). Also physiological conditions affect resistance (Rechav, 1992).

Resistance of cattle to Hyalomma species was studied under field conditions as related to age and breed. These observations showed clear evidence that animals

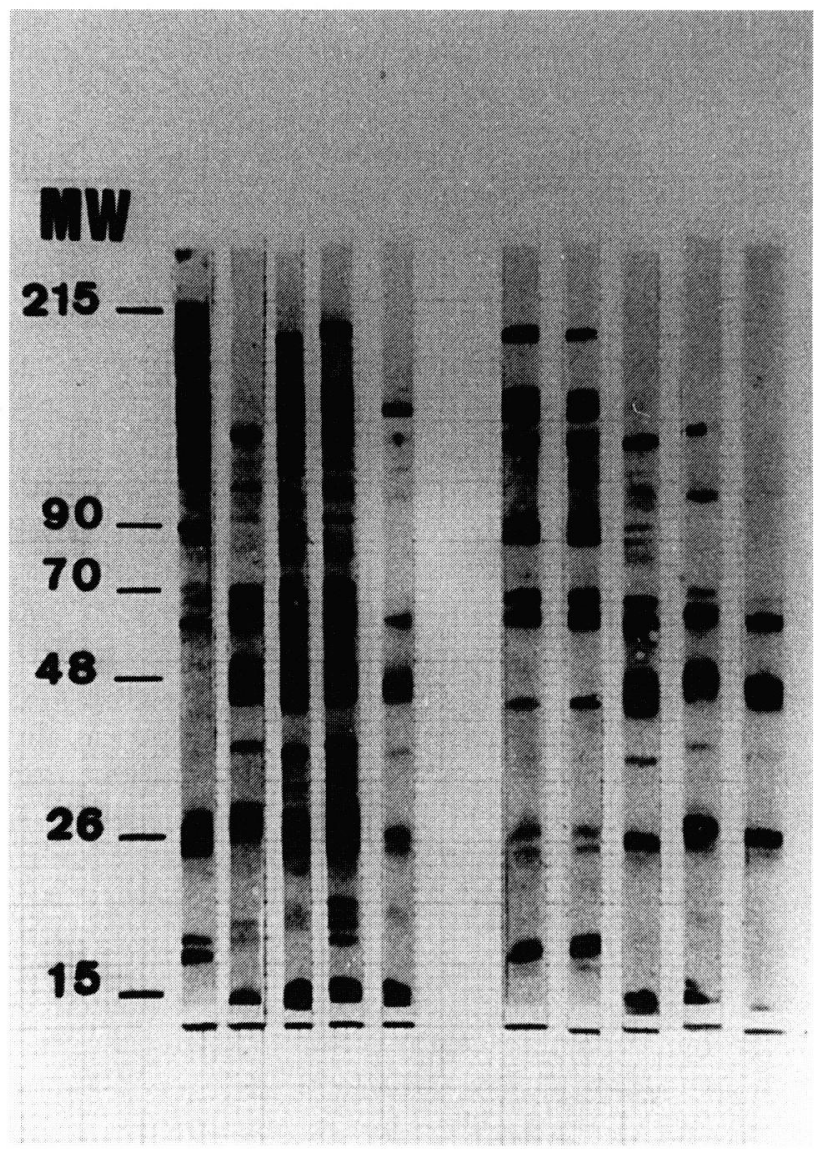

Fig. 6. - Antigens recognized by sera of old native breed calves (right) and old purebred calves (left) in 5-day-fed salivary gland antigens of Hyalomma spp. ( $H$. marginatum, $H$. detritum, $H$. anatolicum, $H$. lusitanicum) ticks. 
below one year of age carried light infestations and cattle older than four years carried heavier infestations. Latif (1984a) observed the same phenomenon and tried to explain it as a consequence of the grooming activity of the mothers that reduced tick infestations of the young animals. In the case of Hyalomma, the ticks are located in regions difficult to groom both in young and old animals (in our observations $65.5 \%$ in testicule or mammary glands and $26.3 \%$ in the groin). On the other hand, animals below one year had been exposed to ticks for only one season but did not acquire parasites, and older cattle were exposed for four or more seasons acquired more parasites. This suggests that animals below one year of age are naturally resistant to Hyalomma species but that resistance decreases subsequently. Transmission of protective antibodies with colostrum has been often offered as an explanation of resistance in the young. This argument has little foundation, the mothers themselves do not exhibit resistance to ticks and the colostral antibodies are known to persist for only about two months in the circulation of the calf (Klauss et al., 1969). An alternative explanation for the resistance of young calves is through some natural immune resistance that is inhibited during the first exposures to the arthropods, an increase in the host's age and the number of exposures resulting in greater parasitic loads.

Genetics also plays an important role in tick infestation in different breeds of cattle (Tatchell, 1987; Rechav, 1992). We confirmed here that, native breed are more resistant than purebred. Some studies, (Fivaz \& Norval, 1990) showed that Bos indicus cattle was more resistant than Bos taurus cattle to the brown ear tick Rhipicephalus appendiculatus Neuman (1901) and to the bont tick Amblyomma hebraeum Koch (1844) (Norval et al., 1988; Fivaz et al., 1991). Rechav \& Kostrzewski (1991), reported a significant difference in the number of Boophilus decoloratus Koch (1844) infesting Santa Gertrudis, Bonsmara, Africaner, Brahman and Nguni breeds. Resistance levels of each breed to Boophilus decoloratus Koch (1844) were positively correlated with the amount of Bos indicus gene in the breed. George et al. (1985), found that Herford cattle carry more ticks than Brahman and that most breeds of Bos indicus can acquire high levels of resistance to ticks when compared to European breeds of Bos taurus.

In our study, we did not observe any significant effect of the breed on the weight of the collected females. A similar observation was made by Fivaz et al. (1991) on infestation by Amblyomma bebraeum. Interaction of young age and breed, produced the most significant resistance (Tables I, II). Interaction of older age and native breed produced medium resistance. The combination of older age and purebred exhibited the least resistance. There is a clear evidence that the inhibitory influence of native breed on the infestation is able to be partially compensated by the inhibitory effect of age. The results in Tables I and II, permit separation of the age breed interaction in three groups with different degrees of resistance. The most resistant animals were the young calves. The interaction agebreed was more expressed through the mechanism that inhibited attachment than through the mechanisms that affected feeding. The age-breed interaction appeared to influence feeding only at the older age purebred, which showed more susceptibility than older age and native breed.

We observed great variability of antibody responses to ticks throughout the year in young or old native cattle or old purebred cattle. The peak of antibody production corresponded to the peak of tick infestation. It seems, therefore, that regular antigenic stimulation is necessary to maintain the antibody response to Hyalomma spp., and that antibody response to ticks appears to be transient under field conditions. The variability of antibody response was also important among animals and this confirms the findings of Rechav et al. (1990). In native breed antibody responses were more transient. We wonder whether this is the result of a poorer antigenic stimulation, because the native breed animals had fewer ticks, or whether the purebred calves responded to antigens not related to resistance which are overlooked by native breeds.

The immune response of young animals to ticks to elucidate the mechanism involved in their resistance was not investigated. But, we have found that young local breed animals responded to a number of antigens above $20 \mathrm{Kd}$ which were not recognized by young purebred. We believed that this difference may be a reflection of the mechanisms that make native calves more resistant than purebred. The humoral response to these antigens may be responsible for the young native animals to carry fewer and lighter ticks. There was no correlation, however, between the number of antigens recognized and the level of antibodies in young native or young purebred calves, as well as in adult native and adult purebred.

The adult animals had more and better feeding ticks. There is an inverse relationship between the level of antibodies and resistance. This, in turn, would suggest the occurrence of immunosuppression. The abundance and widespread distribution of ticks in the world indicates that these organisms are quite successful in avoiding the host's immunity mechanism. In retrospect the success of ticks to persist in nature arouses the suspicion that they may able to manipulate the host's immunity. This notion is supported by our findings and those by Barriga et al. (1991). 


\section{REFERENCES}

BALASHOV Y.S. Blood-sucking ticks (Ixodidae): Vectors of diseases of man and animals. Miscellaneous Publication of the Entomological Society of America, 1972, 8, 161-376.

Barriga O.O., Andujar F. \& AndRzejeski W.J. Manifestation of immunity in sheep repeatedly infested with Amblyomma americanum ticks. Journal of Parasitology, 1991, 77, 703-709.

BROWN S.J. Effect of host age on the expression of acquired resistance to ticks. Experientia, 1984, 40, 199-200.

Engvall E. \& Perlman P. Enzyme Linked immunosorbant assay (ELISA). Quantitative assay of immunoglobulin G. Immunochemistry, 1971, 8, 871-874.

Fivaz B.H. \& NoRval R.A.I. Immunity of the ox to the brown ear tick Rhipicephalus appendiculatus. Experimental and Applied Acarology, 1990, 8, 51-63.

Fivaz B.H., Nurton J.P. \& PETney T.N. Resistance of restrained Bos taurus dairy bull calves to the bont tick Amblyomma bebraeum (Acarina: Ixodidae). Veterinary Parasitology, 1991, 38, 299-315.

George J.E., Osbum R.L. \& Wikel S.K. Acquisition and expression of resistance by Bos indicus and Bos indicus X Bos taurus calves to Amblyomma americanum infestation. Journal of Parasitology, 1985, 71, 174-182.

Johnston T.H. \& BAnCrofT M.J. A tick-resistant condition in cattle. Proceeding Royal society of Queensland, 1918, 30, 209-317.

Klauss G.B., BennetT A. \& Jons E.W. A quantitative study of the transfer of colostral immunoglobulins to the new born calf. Immunology, 1969, 16, 293-299.

LATIF A.A. Resistance to natural tick infestations in different breeds of cattle in the Sudan. Insect Science and its Application, 1984a, 5, 95-97.

LATIF A.A. Resistance to Hyalomma anatolicum anatolicum Koch (1844) and Rbipicephalus evertsi Neumann (1897) (Ixodoidae/Ixodidae) by cattle in the Sudan. Insect Science and Application, 1984b, 6, 509-511.

Lowry O.H., Rosebrough N.J., Farr A.L. \& Randall R.J. Protein measurement with the folin phenol reagent. Journal of biological chemistry, 1951, 193, 265-275.

Morel P.C. Morphologie et biologie des tiques d'Ethiopie. Document polycopié. Enseignement. Institut d'élevage et Médecine Vétérinaire des pays tropicaux (1976), 326 p.

MORRISON W.I. Immunological control of ticks and tick-borne parasitic diseases of livestock. Parasitology, 1989, 98, S69S85.

Norval R.A.I., Floyd R.B. \& KerR J.D. Ability of adults of Amblyomma hebraeum (Acarina: Ixodidae) to feed repeatedly on sheep and cattle. Veterinary Parasitology, 1988, 29, 351-355.

Rechav Y., Dauth J. \& Els D.A. Resistance of Brabman and Simmentaler cattle to African ticks. Onderstepoort Journal of Veterinary Research, 1990, 57, 7-12.

RECHAV Y. \& KOSTRZEWSKI M.W. Relative resistance of six cattle breeds to the tick Boophilus decoloratus in south Africa. Onderstepoort Journal of Veterinary Research, 1991, 58, 181-186.
ReCHaV Y. Naturally Acquired resistance to ticks. A global view. Insect science and its Application, 1992, 13(4), 495504.

RECHAV Y. \& HAY L. The effects of nutritional status of rabbits and sheep on their resistance to the ticks Rbipicephalus evertsi evertsi and Rhipicephalus appendiculatus. Experimental Applied of Acarology, 1992, 15, 171-179.

Snedecor G.W. \& Cochran W.G. Statistical Methods, 7 th edt., Iowa State University Press, Iowa, 1980.

STEELman C.D. Effects of external and internal arthropod parasites on domestic livestock production. Annual Review of Entomology, 1976, 21, 155-178.

TATCHELl R.J. Interactions between ticks and their hosts. International journal for Parasitology, 1987, 17(2), 597606.

Tsang V.C.W., Peralta J.M. \& Simons A.R. Enzyme-linked Immunoelectro-transfer blot technic (EITB) for studying the specificities of antigens and antibodies. Separated by gel electrophoresis. Methods in enzymology, 1983, 92, 377-391.

Wharton R.H., Utech K.B.W. \& Turner H.G. Resistance to the cattle tick, Boophilus microplus in a herd of Australian Illawarra Shorthorn cattle: Its assessment and heritability. Australian journal of Agricultural Research, 1970, 21, 163-168.

WILKINSON P.R. Observations on infestations of undipped cattle of British breeds with the cattle tick, Boophilus microplus (Canestrini). Australian Journal of Agricultural Reseach, 1955, 6, 655-656.

Reçu le 5 juin 1996 Accepté le 24 janvier 1997 